\title{
LA POLÍTICA LIBERAL Y LAS OBVENCIONES PARROQUIALES EN EL OBISPADO DE MICHOACÁN, 1821-1860*
}

\author{
POR \\ Moisés ORnelas HeRnÁndeZ \\ Universidad Nacional Autónoma de México
}

\begin{abstract}
RESUMEN
El gobierno liberal promovió la ley de obvenciones y derechos parroquiales en 1857 buscando resolver un antiguo problema entre la población y los curas por los abusos que cometían en el cobro del arancel, al administrar sacramentos y otras actividades del culto. La intensidad del conflicto y la disputa que el asunto originó entre el poder civil y eclesiástico en la diócesis de Michoacán constituyen el tema principal del presente trabajo. Para ubicar el problema en su realidad local se explican sus antecedentes en la diócesis antes de la llegada del obispo Clemente de Jesús Munguía; estudiando los conflictos que el cobro de obvenciones provocó en los pueblos.
\end{abstract}

PALABRAS CLAVE: obvenciones parroquiales, gobierno liberal, ley de 1857, obispo Munguía

\section{THE LIBERAL POLITICS AND THE PAROCHIAL PERQUISITES IN MICHOACAN'S BISHOPRIC, 1821-1860}

\begin{abstract}
The liberal government promoted the law of perquisites and parochial rights in 1857 seeking to solve a former problem between the population and the priests for the abuses that they were committing in the collection of the duty, on having administered sacraments and other activities of the worship. The intensity of the
\end{abstract}

\footnotetext{
* Este trabajo forma parte de mi tesis doctoral: «A la sombra de la revolución liberal. Iglesia, política y sociedad en Michoacán, 1821-1870», que realicé en el Centro de Estudios Históricos de El Colegio de México, bajo la dirección del doctor Andrés Lira González.
} 
conflict and the dispute that the matter originated between the civil and ecclesiastic power in Michoacán's diocese they constitute the principal topic of the present work. To locate the problem in his local reality his precedents are explained in the diocese before the arrival of the bishop Clemente de Jesus Munguía; studying the conflicts that the collection of perquisites provoked in the peoples.

KEY WORDS: Parochial Perquisites, Liberal Government, Law of 1857, Bishop Munguía

Recibido/Received 02/03/2011

Aceptado/Accepted 30/04/2011

El 11 de abril de 1857, el presidente Ignacio Comonfort aprobó la ley sobre derechos y obvenciones parroquiales que derogó los aranceles vigentes que pugnaran con la ley, por tanto, suprimió toda prestación de servicio personal y tasaciones en los pueblos y haciendas para cubrir las referidas obvenciones. Otorgó la exención del pago a los pobres que no contaran con la cantidad mínima de subsistencia y facultó a la autoridad política local el calificar la pobreza de los fieles para gozar del beneficio y vigilar su cumplimiento. Así, convirtió al poder civil en árbitro que castigaría a los curas con el triple de lo cobrado, devolviendo al interesado su parte y compartiría la multa por mitad con la cárcel municipal. El cobro indebido de los derechos y condicionar los sacramentos propiciaría en casos extremos el destierro del cura; asimismo, ordenó que la ley debía fijarse en los cuadrantes de las parroquias, salas municipales y juzgados. ${ }^{1}$

José María Iglesias, ministro de Justicia y Negocios Eclesiásticos, acompañó la ley con una circular a los gobernadores en la que subrayó los objetivos que perseguía a fin de beneficiar a los pobres. Insistió en que la medida consistía en un acto de justicia social del gobierno liberal que buscaba dispensar a los fieles del pago forzado de los sacramentos, que se había convertido en un escándalo entre el pueblo católico. No dejó de reconocer; sin embargo, el derecho que asistía a los curas a cobrar por su trabajo, pues afirmó categórico: «quien sirva al altar coma del altar», pero advirtió que no sería a expensas de los desprotegidos. El poder civil no tuvo otra opción que intervenir para proteger a los fieles. ${ }^{2}$

En efecto, la llamada revolución liberal mexicana contempló una serie de reformas políticas de carácter social dirigidas a debilitar la participación de la Igle-

\footnotetext{
${ }^{1}$ Ley de 11 de abril de 1857 sobre derechos y obvenciones parroquiales, en Nuevo Código de la Reforma. Leyes de Reforma. Colección de las disposiciones que se conocen con este nombre, publicadas desde el año de 1855 al de 1868 formada y anotada por el Lic. Blas José Gutiérrez, México, Suprema Corte de Justicia de la Nación, 2009, tomo II, parte 1, Edición facsimilar, pp. 537-544.

${ }^{2}$ Ibidem.
} 
sia en la vida pública. Sus mayores dificultades se presentaron a raíz de las leyes liberales que se publicaron entre los años de 1855 a 1860 que afectaron los intereses y privilegios de la Iglesia; por ejemplo, el fuero eclesiástico, la desamortización de la propiedad eclesiástica, el registro civil, la jura de la Constitución de 1857, y la ley de obvenciones, por mencionar las más importantes. Ello propició un irremediable conflicto que dañó la relación de ambas instancias de poder que culminaría con la separación definitiva de la Iglesia y el Estado.

El gobierno liberal, como advertimos, promovió la ley de obvenciones y derechos parroquiales para resolver un añejo problema que la población tenía con los curas por los abusos que cometían en el cobro del arancel, al administrar sacramentos y otras actividades propias del culto. La gravedad del conflicto y la lucha social que el cobro originó entre el poder civil y eclesiástico en la diócesis de Michoacán constituyen el tema principal del presente trabajo. A fin de ubicar el problema en su realidad local se rastrean sus antecedentes en la diócesis antes de la llegada del obispo Clemente de Jesús Munguía, -que respondería a la Ley Iglesias con un discurso radical, que enfrentaría a las dos esferas de poder; analizando los conflictos que el cobro de obvenciones suscitó en los pueblos.

La coexistencia del pindecuario ${ }^{3}$ y el arancel eclesiástico como dos medios de cobro en el obispado elevaron las fricciones con la feligresía que reclamó la mediación del poder civil para frenar los abusos de los curas; por su parte, los eclesiásticos hicieron lo propio con la mitra frente a la omisión de los fieles. Con todo, la fuerte oposición indígena a las obvenciones al rayar la primera mitad del siglo XIX, obligó la intervención de Melchor Ocampo, quien promovió una reforma del arancel para adecuarlo a la realidad social y económica de los pueblos del obispado. Sin embargo, la jerarquía eclesiástica rechazó la propuesta, alegando la ausencia del Patronato, el cual puede verse como el antecedente directo del conflicto con la mitra de Michoacán que se radicalizaría con la ley de obvenciones del 11 de abril de 1857.

\section{CiUdADANÍA LIBERAL VERSUS INDÍGENAS: EL COBRO DE LAS OBVENCIONES}

Durante el periodo colonial tardío, en las distintas diócesis de la Nueva España, un motivo frecuente de fricción entre curas y feligresía indígena fue el cobro de los derechos parroquiales por el ministerio espiritual, sustento indispensable de los sacerdotes. La exacción directa hizo aparecer al cura frente a

\footnotetext{
${ }^{3}$ Pindecuario de «pindecua», costumbre, fue el nombre indígena que recibió el documento en el que se asentaban las obligaciones que los fieles indígenas por costumbre cubrirían durante todo el año litúrgico por los servicios del culto. Era una suerte de tasación o encabezamiento convenido entre los feligreses y el sacerdote cura pastor.
} 
sus feligreses como alguien que ponía en venta los sacramentos provocando la disputa con los indígenas que, de suyo, mostraban una fuerte resistencia al pago de los derechos. El incremento en la frecuencia del conflicto lo provocaron cambios internos en la Iglesia siendo los principales la secularización de las parroquias y la promulgación del arancel del arzobispo Lorenzana en 1749 y 1767 , respectivamente. ${ }^{4}$

La secularización de las parroquias quitó de la administración de las doctrinas a los religiosos y su lugar fue ocupado por curas seculares. La coyuntura fue aprovechada por los indígenas que pensaron que el pago de derechos se había suspendido, confusión que suscitaría fricción con los nuevos curas. En ese escenario, los feligreses y el sacerdote tuvieron la oportunidad de llegar a un acuerdo verbal cuando las cantidades estipuladas por el arancel fueran elevadas; sin embargo, el convenio no logró contener las dificultades y exigió una respuesta de la Iglesia al problema. El 7 de julio de 1767, el arzobispo Lorenzana consciente de que en las parroquias prevalecía la costumbre y el convenio en los derechos eclesiásticos estableció un nuevo arancel que buscó resolver las fuertes disputas. ${ }^{5}$

El arancel ordenó a los curas ceñirse a sus instrucciones, pero en la práctica el principio que operó fue que entraría en vigor sólo si la parroquia o el pueblo lo solicitaban y, en todo caso, si el sacerdote lo consentía. En la mayoría de los pueblos de indios prevalecieron acuerdos locales sobre los derechos que mezclaron los pagos en efectivo, en especie y en servicios personales; ${ }^{6}$ en suma, la Iglesia buscó terminar con los pleitos estableciendo una regla fija a través del arancel a fin de uniformar y centralizar la administración parroquial.

La flexibilidad de la propuesta del arzobispo, que permitió el acuerdo mutuo de la aplicación del arancel a curas y feligresía, amén del hincapié que hizo de perdonar a los pobres el pago de los derechos, abrió la puerta a los conflictos. No sería gratuito, por tanto, que los indígenas invocaran el arancel para contrarrestar la costumbre del cura en el cobro señalando las arbitrariedades que realizaba en común acuerdo con las autoridades locales que denotaban su falta de caridad cristiana. En esa línea el arancel buscó eliminar los servicios personales extraordinarios no retribuidos e involuntarios a nombre de la parroquia que sería una fuente de pleitos legales.

La reforma de intendentes de 1780 propiciaría otro auge de pleitos, pues se inclinó por no exigir derechos excesivos y que su cobro lo regiría un arancel

${ }^{4}$ W. B. TAYLor, Ministros de lo sagrado. Sacerdotes y feligreses en el México del siglo XVIII, México, El Colegio de Michoacán, Secretaría de Gobernación, El Colegio de México, 1999, vol. II, p. 631 .

${ }^{5}$ Ibidem. p. 635.

${ }^{6}$ Ibidem. 
equitativo que se aplicaría en función del nivel de pobreza de los fieles. La responsabilidad de supervisar los aranceles recayó en los subdelegados, quienes buscaron la fiel aplicación que derivó en el enfrentamiento con los sacerdotes. ${ }^{7}$ En suma, los curas defendieron a finales del periodo colonial las prácticas tradicionales cuando todo apuntaba a uniformar y centralizar, pues se mostraron flexibles a negociar la forma de pago. ${ }^{8}$

En el obispado de Michoacán, que comprendía una extensa jurisdicción episcopal, con curatos ubicados en los estados de San Luis Potosí, Guanajuato, México y Michoacán, este último, sede del obispado, el cobro de las obvenciones no fue la excepción, pues provocó, al igual que en el resto de las diócesis, un conflicto social que databa de tiempo coloniales.

El problema del cobro de las obvenciones se mantuvo vigente en el obispado a lo largo del siglo XIX. Lo analizaremos a partir de la época en que fue promulgada la Constitución Política de la Monarquía Española, en Cádiz en 1812, que reavivó el conflicto entre curas y feligresía. Las dificultades jurídico-políticas que desató encontraron eco entre los indígenas, en particular, el decreto del 9 de noviembre de 1812 que abolió los antiguos privilegios corporativos: la mita y los servicios personales, otorgando la ciudadanía a los habitantes. ${ }^{9}$

La aplicación del proyecto gaditano de ciudadanización tuvo sus efectos inmediatos en los pueblos indígenas, sobre todo en materia fiscal, pues a partir de ese momento las contribuciones civiles y eclesiásticas que deberían cubrir aumentarían de manera notable. Su nueva condición de ciudadanos obligaría a los indígenas, el cuerpo menos favorecido del viejo orden social, a pagar fiscalmente en la misma proporción que lo hacia el resto de la población.

En la diócesis de Michoacán, los párrocos y religiosos continuaron haciendo uso del decreto de 9 de noviembre de 1812 para obligar a las comunidades indígenas a cubrir el pago de las obvenciones parroquiales. Los conflictos sociales que provocó la aplicación del decreto gaditano entre los indígenas del obispado fueron numerosos y se prolongaron durante toda la primera mitad del siglo XIX. Pero también se dieron casos en los que los propios curas del obispado llamaron la atención sobre los efectos negativos que tenía sobre las

\footnotetext{
${ }^{7}$ Ibidem. p. 650

${ }^{8}$ Pindecuario de «pindecua», costumbre, fue el nombre indígena que recibió el documento en el que se asentaban las obligaciones que los fieles indígenas por costumbre cubrirían durante todo el año litúrgico por los servicios del culto. Era una suerte de tasación o encabezamiento convenido entre los feligreses y el sacerdote cura pastor.

${ }^{9}$ Decreto del 9 de noviembre de 1812 sobre la abolición de las mitas, exención de servicio personal, y otras medidas a favor de los indios, en M. DuBlán y J. M. LozANo, Legislación mexicana o colección completa de las disposiciones legislativas expedidas desde la independencia de la república, México, Imprenta del Comercio, 1876, tomo I, pp. 396-397.
} 
comunidades, y sobre ellos mismos, la carga fiscal excesiva que se hacía recaer sobre las poblaciones indígenas empobrecidas y que les impedía seguir apoyando la manutención del cuerpo parroquial. ${ }^{10}$

Varias comunidades indígenas protestaron por el cobro de los derechos parroquiales. El 2 de octubre de 1820, cuando Luis Atanasio Aguilar, regidor del ayuntamiento de Valle del Maíz, San Luis Potosí, a nombre de los indígenas, dio cuenta al alcalde de los abusos que cometía el franciscano Miguel Gilavert en el cobro de las obvenciones. ${ }^{11}$ El regidor comentó las modificaciones que pretendía llevar a cabo en el cobro a los indígenas, apoyado en el decreto gaditano que abolió el servicio personal que daban a las corporaciones, funcionarios públicos y, sobre todo, a los párrocos. En su lugar, según interpretó el franciscano, los indígenas estaban obligados a cubrir en efectivo y en la cantidad que un ciudadano español pagaba las obvenciones, como lo hacían el resto de los feligreses. ${ }^{12}$

Esta exigencia provocó confusión en las autoridades civiles de Valle del Maíz. Por un lado, consideraron que el religioso procedía de manera arbitraria y que no tenía facultades para cobrar el derecho y, por otro, suponían que los privilegios indígenas en materia de obvenciones continuaban vigentes, pues las autoridades eclesiásticas del obispado de Michoacán no se habían pronunciado sobre el particular. Las autoridades locales cuestionaron el cambio en el arancel, ya que, en su opinión, los pueblos indígenas saldrían perjudicados con la derogación de las exenciones, y los únicos beneficiados serían los párrocos. El regidor hizo una consulta legal en la capital potosina, en ella quedó confirmada la interpretación del franciscano, pues el decreto del 9 de noviembre de 1812 hacía referencia a las obvenciones estipuladas en la tasación, en las cuales los indios no pagaban debido a los servicios personales que brindaban a los párrocos, así los indígenas, una vez abolido el servicio, quedaban obligados a cubrir los derechos como el resto de los ciudadanos pero teniendo en cuenta el arancel estipulado para españoles, mulatos e indios con sus divisiones. ${ }^{13}$

${ }^{10}$ Las autoridades del Imperio mexicano se ocuparon de los indígenas reiterando lo dispuesto por las Cortes españolas. El decreto de 22 de febrero de 1822, prohibió el cobro de tributos (abolidos desde 1810 ), del medio real de hospital (que pagaban los indios tributarios para el mantenimiento del Hospital de Naturales), y del medio real de ministros (destinado al sostenimiento del Juzgado General de Indios), por haber cesado los objetos a que estaban destinados, Cfr. A. LiRA GonZÁlez, Comunidades indígenas frente a la ciudad de México. Tenochtitlan y Tlatelolco, sus pueblos y barrios, 1812-1919, México, El Colegio de México, Centro de Estudios Históricos, 1995, p. 55.

${ }^{11}$ Informe de Luis Atanasio Aguilar, regidor del ayuntamiento del pueblo del Valle del Maíz, San Luis Potosí, a Manuel Fernando Ortiz de Zarate, alcalde de dicho pueblo sobre las modificaciones que fray Miguel Gilavert, vicepárroco y guardián del convento de San Francisco, pretende realizar en el cobro de los derechos parroquiales, en Archivo Histórico Casa de Morelos, en adelante (AHCM), Diocesano/Gobierno/Correspondencia/Autoridades Civiles/1820-1827/, exp. 38, caja 34, año 1820, 13 fs.

${ }^{12}$ Ibid.

${ }^{13}$ Ibid.

Hispania Sacra, LXIII

128, julio-diciembre 2011, 681-706, ISSN: 0018-215-X 
La presión ejercida por el religioso llevó a los indígenas, apoyados por las autoridades civiles, a oponerse a cualquier innovación en materia de derechos parroquiales. Solicitaron a la mitra intervenir para encontrar una salida al problema. No hubo necesidad de esperar el dictamen, pues el alcalde del lugar lo convenció de cobrar a los indígenas conforme al arancel vigente. El proceder de los indígenas sirvió de guía a otros pueblos potosinos; por ejemplo, el de Río Verde, que buscó el apoyo del ayuntamiento para llevar sus quejas a la mitra, a fin de pagar los derechos conforme a sus posibilidades y regidos por el arancel correspondiente a su clase social. ${ }^{14}$

En la diócesis de Michoacán, la insistencia de que los indígenas no quedaran exentos del pago de obvenciones propició la disputa, pues los montos exigidos se incrementarían, así que las protestas no tardaron en presentarse. El 9 de marzo de 1821 los indígenas de San Francisco Ixtlán, a través del alcalde, buscaron persuadir a Manuel de la Bárcena, arcediano y gobernador de la mitra de Michoacán, de que los montos de los derechos parroquiales se mantuvieran conforme a lo acostumbrado en el arancel vigente y que no sufrieran modificación alguna a consecuencia del decreto de las Cortes del 9 de noviembre de 1812 .

Las exigencias de los indígenas cobraron un matiz particular. Primeramente, solicitaron que las obvenciones a las que estaban sujetos no sufrieran modificación a causa del decreto de las Cortes, lo que llevaría a pensar que aceptaban pagarlos. Más adelante cambiaron de opinión y señalaron al gobernador de la mitra que no estaban dispuestos a cubrir ningún derecho por concepto de servicios religiosos, ya que sería injusto y contrario a sus intereses, máxime si se tomaba en cuenta que el pueblo indígena había construido el templo. ${ }^{15}$

A cambio de quedar exentos, los indígenas ofrecieron al canónigo mantener en buenas condiciones materiales el templo. Recordaron que, desde su fundación, los habitantes del pueblo construyeron y reedificaron el templo realizando gastos como fueron la compra de las campanas, los adornos y otras construcciones anexas. Del mismo modo, subrayaron el apoyo que dicho pueblo brindó a las tropas realistas durante la lucha insurgente. Los argumentos surtieron

14 Por decreto de 17 de septiembre de 1822, el congreso constituyente del Imperio mexicano prohibió clasificar a los ciudadanos por su origen, dejando, sin embargo, la clasificación para el sólo efecto del pago de aranceles en los juzgados y para el de obvenciones y derechos parroquiales. Señal del reconocimiento de la pobreza generalizada entre los indígenas y las castas, $C f r$. A. LIRA GonZÁLEZ, op. cit., p. 55.

15 Solicitud de Miguel Villanueva y Juan Atanasio Gómez, alcalde constitucional y regidor, del pueblo de San Francisco Ixtlán, al gobierno de la mitra de Michoacán para que los indígenas del lugar permanezcan bajo el arancel vigente en el obispado hasta 1821 para el cobro de los derechos parroquiales en AHCM, Diocesano/Gobierno/Correspondencia/Autoridades Civiles/1820-1827/exp. 44, caja 34 , año 1821,5 fs. 


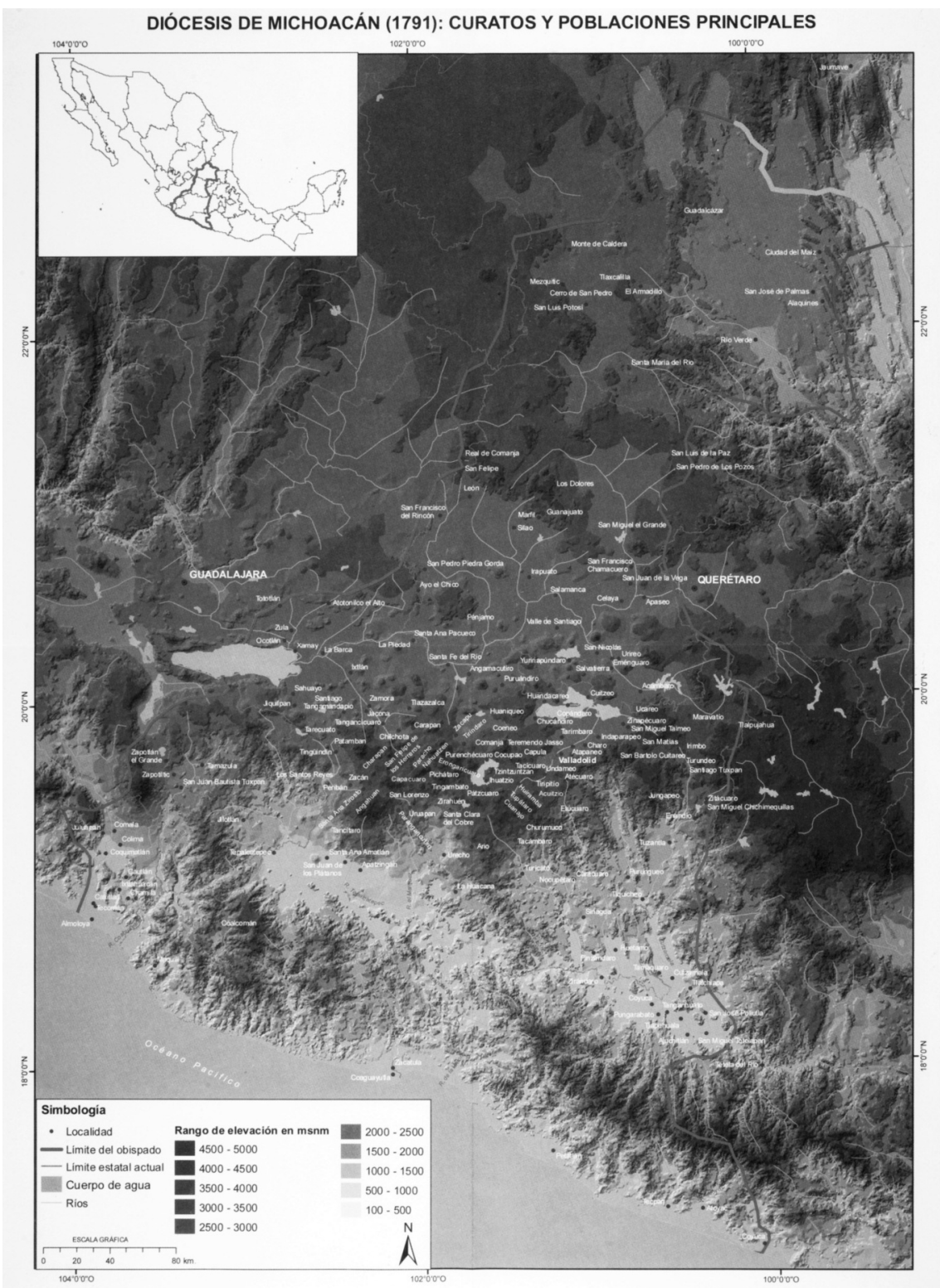

Fuente: D. A. BRADING y Ó. MAZín, El gran Michoacán en 1791. Sociedad e ingreso eclesiástico en una diócesis novohispana, México, El Colegio de Michoacán, El Colegio de San Luis, 2009.

Hispania Sacra, LXIII

128, julio-diciembre 2011, 681-706, ISSN: 0018-215-X 
efecto, pues el 4 de junio de 1821 Manuel de la Bárcena aceptó la propuesta, por lo que fueron exentados del pago. Debe subrayarse la capacidad mediadora del ayuntamiento frente al canónigo, lo que evitó un conflicto de mayores consecuencias. ${ }^{16}$

Suprimir el pago de obvenciones mediante el pindecuario, ordenado por la ley de las Cortes, sembró inquietud social en los pueblos de la diócesis, pues alteraba la tradición al sujetarlos al arancel. Las protestas por los efectos negativos que producía esta disposición no fueron patrimonio exclusivo de los pueblos indígenas de la meseta tarasca, ya que incluso los párrocos la hicieron suya aunque con diferente matiz e intención. El cura de Purenchécuaro informó a Antonio Castro, gobernador de Michoacán, los problemas que en la región ocasionaba la legislación en materia de obvenciones, pues prevalecía la confusión entre curas y autoridades locales al llevar a la práctica la ley gaditana. El subprefecto de Pátzcuaro, a finales de septiembre de 1825, sin dar aviso a la mitra, incautó los ingresos del pindecuario, que servían para el sostenimiento del párroco, apoyado en la abolición decretada en 1812, y en su lugar estableció un arancel que acatarían todos los ciudadanos, incluidos los indígenas. La medida perjudicó al párroco y feligreses, y causó alarma en los indígenas que tendrían que pagar más de lo acostumbrado. ${ }^{17}$

El cura dejó al descubierto los peligros y problemas que la supresión del pindecuario acarrearía. Apuntó que los recursos que el arancel produciría serían insuficientes, incluso en el caso de que los indígenas pagaran los derechos establecidos. Esta amenaza alarmó al párroco porque, a su juicio, los indígenas pasaban por una situación económica grave, y sería muy difícil que cubrieran a tiempo los derechos por conceptos de bautismo, matrimonio y entierros, pues durante mucho tiempo lo hicieron con el pindecuario. Los indígenas se negaron a acatar la disposición del subprefecto en materia de obvenciones, ya que el arancel de españoles, al que quedarían sujetos, representaba una contribución mayor. ${ }^{18}$

Si bien la medida liberal que ordenó su desaparición en el papel afectaba tanto a indígenas como a párrocos, serían los segundos quienes de manera directa resultarían perjudicados. La tasación como también se le llamaba a esta forma de pago eclesiástica, garantizaba su cotidiano sustento, y se realizaba en especie. Las condiciones se establecían de común acuerdo entre el pueblo y el

\footnotetext{
16 Ibid.

17 Solicitudes de los pueblos de Purenchécuaro, Tiríndaro, San Pedro Cocucho, Capacuaro y Zirosto a Antonio Castro, gobernador de Michoacán para que no desparezca la obligación de pagar los derechos parroquiales con base en el pindecuario, en AHCM, Diocesano/Gobierno/Correspondencia/ Autoridades Civiles/1820-1827, exp. 74, caja 34, año 1825, 7 fs.

18 Ibid.
} 
eclesiástico, que los contratantes respetaban en la mayoría de los casos. El nuevo ordenamiento, nada garantizaba que los indígenas cumplieran cabalmente, lo que haría difícil la vida de los ministros. Motivados por esta amenaza y por el hecho de que el subprefecto no había tomado la opinión de la mitra, llevaron la queja al Congreso de Michoacán el 11 de octubre de 1825.19

Hacia finales de la tercera década del siglo XIX, los conflictos continuaron presentándose con cierta regularidad. Los informes en materia de obvenciones crecieron dando cuenta de los excesos de autoridades locales, párrocos y, en menor medida, de la feligresía. El 11 de abril de 1827 Agustín Sámano, subprefecto de Ajuchitlán, informó a la mitra los abusos que, en nombre de la religión, algunos eclesiásticos realizaban en pueblos de su partido aprovechándose de la ignorancia de los indígenas. ${ }^{20}$ Esta vez consistían en obligarlos a pagar en dinero las obvenciones, acción que llevaban a cabo coludidos con los alcaldes, quienes llegaron incluso a exigir a los indígenas prestar servicios personales. ${ }^{21} \mathrm{El}$ subprefecto envió una circular anunciando la prohibición y ordenando que, a partir de ese momento, los alcaldes y sacerdotes que reincidieran serían multados. ${ }^{22}$

Lo sucedido en ese pueblo permite advertir dos aspectos interesantes del problema, el primero, las dificultades de aplicación de la ley gaditana y, el segundo, los márgenes de acción política de los cuales se valieron las autoridades civiles y sacerdotes, en detrimento de los indígenas. Con seguridad, ese hecho se presentó en otros pueblos de la diócesis, facilitado por la distancia geográfica con las subprefecturas, que permitió a curas y autoridades locales actuar con libertad.

Otro caso de desavenencia entre indígenas y curas ocurrió en Erongaricuaro, cuyo alcalde informó el 12 de febrero de 1829 al subprefecto de Pátzcuaro los problemas que trajo la negativa del cura a exentar del pago de obvenciones a los indígenas, tensando la relación con la feligresía. ${ }^{23}$ La magnitud del conflicto llevó a solicitar a la mitra la salida del cura, quien se mostraba inflexible, incluso para perdonar el pago de los derechos en los entierros a indígenas pobres siendo su respuesta común «que los salen si no tienen el dinero».24

\footnotetext{
${ }^{19}$ Ibid.

${ }^{20}$ Informe de Agustín Sámano, subprefecto del partido de Ajuchitlán al gobernador de la mitra del obispado de Michoacán sobre las irregularidades que cometen los religiosos en dicho partido en, AHCM, Diocesano/Gobierno/Correspondencia/1822-1828/ exp. 122, caja 421, año 1827, 5 fs.

${ }^{21}$ Ibid.

22 Ibid.

${ }^{23}$ Informe del Alcalde Primero del pueblo de Erongaricuaro al Subprefecto de Pátzcuaro sobre los problemas surgidos entre los indígenas y el párroco del lugar por el cobro de los derechos parroquiales, en AHCM, Diocesano/Gobierno/Sacerdotes/Correspondencia/1828-1832/, exp. 136, caja 421, año 1829,8 fs.

${ }^{24}$ Ibid.
} 
La resistencia del párroco levantó a los indígenas en su contra, posición que el alcalde respaldó ante la mitra, ya que consideró que el párroco provocaba la división. Subrayó los esfuerzos que a favor del cura realizaron los regidores del ayuntamiento y él mismo para erradicar la celebración de algunas fiestas y costumbres arraigadas, que obstaculizaban su desarrollo. Sin embargo, el párroco realizó una alianza con los indígenas ancianos para que éstas continuaran sin variaciones, acuerdo que también incluyó el pindecuario. El alcalde subrayó que existió un acercamiento con los indígenas más jóvenes exhortándolos para que se estableciera a la brevedad el arancel y, por tanto, que la tasación dejara de regir, lo que traería beneficios y evitaría los abusos del cura. A fin de zanjar las diferencias surgidas en dicho pueblo, el gobierno estatal instruyó al subprefecto que dejara a sus pobladores en plena libertad de elegir la manera de pagar las obvenciones: pindecuario o arancel..$^{25}$

Desconocemos cómo la mitra interpretó la participación del poder civil en un asunto de competencia eclesiástica, pues era evidente que éste apoyaba la idea de que los pueblos indígenas optaran por el arancel para hacerlos partícipes de la modernidad fiscal. Los casos comentados, causados por la legislación gaditana en materia de obvenciones parroquiales, muestran las complicaciones que provocó en los pueblos indígenas de la diócesis. La persistencia de las obvenciones como problema de interés social en el obispado de Michoacán demandaría la atención de los liberales y generaría fuertes polémicas con los párrocos y, sobre todo, con los obispos de la diócesis.

Gómez de PoRTUgal y Las OBVENCIONES, ¿PINDECUARIO INDÍGENA O ARANCEL?

El problema del pago de obvenciones y derechos parroquiales en la diócesis de Michoacán persistió por una razón de fondo, había dos formas de cubrirlo: el pindecuario y el arancel. Durante la gestión episcopal de Juan Cayetano Gómez de Portugal (1831-1850), la polémica por el cobro se mantuvo como una constante situación que demandó la atención del prelado para resolver los conflictos suscitados entre párrocos y pueblos indígenas. El obispo, en el caso de las obvenciones, mostró siempre una actitud conciliadora y respetuosa, pues trató de encontrar salidas prácticas, sin afectar a los interesados.

Las dificultades que el cobro suscitaba en los curatos del obispado de Michoacán llegaron al conocimiento del presidente de la República, quien el 30 de agosto de 1842 tomó cartas en el asunto. Ordenó a Gómez de Portugal que los párrocos de su diócesis colocaran en los cuadrantes de sus templos el arancel de derechos vigente, pues tenía noticias de que en su diócesis los párrocos se exce-

25 Ibid. 
dían en el cobro contrariando la caridad cristiana, sobre todo en los entierros. ${ }^{26}$ En su descargo, el obispo, desconcertado, hizo saber al Ministerio de Relaciones, el 9 de septiembre de 1842, su extrañeza por las supuestas dificultades que existían en su diócesis. Insistió que no tenía noticia de disturbios a consecuencia del cobro de las obvenciones, ya que el arancel se encontraba a la vista de los feligreses en los cuadrantes de las parroquias. ${ }^{27}$

Si bien es cierto que una constante entre la feligresía del obispado fue quejarse de los abusos de los párrocos, existió también su contraparte cuando los eclesiásticos hicieron lo propio con los fieles. El 17 de agosto de 1848 Seferino Agustín Sánchez, párroco de Tingambato, informó a Gómez de Portugal los problemas que tenía con la feligresía de mayoría indígena, que no pagaba el pindecuario. ${ }^{28} \mathrm{El}$ cura solicitó la intervención del prelado, no sin antes calificar como «apatía» la resistencia de meses que los indígenas del lugar mostraban para cumplir con el pindecuario que era de doce reales por la misa semanal. ${ }^{29}$ El cura explicó al obispo la urgencia de que los indígenas pagaran las obvenciones, pues eran esenciales para su manutención. Señaló la necesidad de actualizar los montos del pindecuario, en consideración a que la población había crecido y, en consecuencia, los gastos de los servicios espirituales. Propuso también la adopción del arancel en lugar de la tasación, argumento recurrente para justificar una reforma al pago de obvenciones ante la resistencia añeja de los indígenas. ${ }^{30}$

El cobro de las obvenciones obligó la intervención de las autoridades locales para frenar los abusos de curas e indígenas, animados siempre por conservar la tranquilidad pública y cuidar que el culto no sufriera interrupción. El 19 de enero de 1848 el ayuntamiento de Purépero envió una solicitud a la mitra para esclarecer la queja que Francisco Cerna hizo contra el cura del lugar José Antonio de la Mora, por abusos en el cobro de los derechos parroquiales. ${ }^{31}$ Reconoció

26 Solicitud del Ministerio de Relaciones Exteriores a Juan Cayetano Gómez de Portugal, obispo de Michoacán, para que se coloquen en los cuadrantes de las parroquias el arancel vigente de cobros de derechos parroquiales para evitar los abusos de los párrocos, en AHCM, Diocesano/Gobierno/Correspondencia/Autoridades Civiles/1840-1847/, exp. 144, caja 39, año 1840, 4 fs. El decreto citado de 30 de agosto de 1842 se encuentra en Mariano Galván Rivera, Nueva colección de leyes y decretos mexicanos en forma de diccionario, tomo 1, p. 380 .

27 Ibid.

${ }^{28}$ Queja de Seferino Agustín Sánchez, párroco del pueblo de Tingambato, contra los indígenas del lugar que se niegan cubrir el pago de los derechos de las obvenciones parroquiales, en AHCM, Diocesano/Gobierno/Siglo XIX/Sacerdotes/Solicitudes/1848-1849/, exp. 368, caja 516, año 1848, 2 fs.

29 Ibid.

30 Ibid.

${ }^{31}$ Informe del presidente del ayuntamiento del pueblo de Purépero al gobernador de la mitra de Michoacán sobre fricciones surgidas con José Antonio de la Mora, párroco de dicho pueblo por el cobro de los derechos parroquiales, AHCM, Diocesano/Gobierno/SigloXIX/Parroquias/Informes/18471851/, exp. 293, caja 244, año 1848, 6 fs.

Hispania Sacra, LXIII

128, julio-diciembre 2011, 681-706, ISSN: 0018-215-X 
que había algunas fricciones entre el cura y la feligresía a causa del cobro, pues aquél no fijó a la vista el arancel. Respetuoso de la labor del cura, solicitó que cumpliera con el arancel como se hacía en Zamora, Jacona y Pátzcuaro. ${ }^{32}$ Una mala aplicación del arancel propiciaba la disputa con el eclesiástico. El 29 de enero de 1848 la mitra prometió solucionar el problema, pero causó extrañeza que el feligrés hubiera acudido al ayuntamiento debiendo dirigirse a las autoridades eclesiásticas, siendo un asunto de su competencia. ${ }^{33}$

No deja de llamar la atención el porqué del interés de las instancias locales en resolver un problema religioso como el cobro de las obvenciones y, sobre todo, encontrar sentido a su preocupación de que los curatos estuvieran atendidos con puntualidad por sacerdotes. A simple vista, podría parecer una contradicción política, ya que la autoridad civil estaría fomentando la religiosidad de la población. Sin embargo, debe tenerse en cuenta que el interés del poder civil en los pueblos se explica en que los asuntos eclesiásticos eran de orden público $\mathrm{y}$, por tanto, entraban en su competencia.

Lo sucedido en Turicato, en la región de Tierra Caliente, el 11 de septiembre de 1850 , puede ayudar a explicar el porqué de la participación del poder civil en asuntos eclesiásticos. El ayuntamiento solicitó a Gregorio Ceballos, gobernador de Michoacán, su intervención ante el vicario capitular del obispado para que el bachiller José María Alvarado, párroco del lugar, regresara del pueblo de Pedernales al que arbitrariamente decidió adoptar como sede de su trabajo pastoral. ${ }^{34}$

Señaló que el regreso del sacerdote se hacía más urgente debido a la demanda de auxilios espirituales que tenía la población por los graves efectos que causó la epidemia de cólera mórbus. Apuntó que habían solicitado a la mitra el regreso del cura de Pedernales, pero que éste se había negado por no privarse de las comodidades materiales que tenía. ${ }^{35}$ En su descargo, el cura argumentó que las razones por las cuales no regresaba se debían a la animadversión de la feligresía hacia su persona, y el precario estado de la parroquia, consideración que fue mal vista. ${ }^{36}$

Ofendidos ayuntamiento y feligresía, se lanzaron contra el cura y cuestionaron su labor pastoral. A los daños causados por la ausencia del sacerdote agregaron los males terrenales, la falta de misa dominical afectaba los ingresos

\footnotetext{
32 Ibid.

33 Ibid.

34 Solicitud del ayuntamiento del pueblo de Turicato a las autoridades de la mitra de Michoacán para que el párroco José María Alvarado fije su residencia en dicho pueblo, en AHCM, Diocesano/Gobierno/Correspondencia/Autoridades Civiles/1848-185, exp., 181, caja 39, año 1850, $6 \mathrm{fs}$.

35 Ibid.
} 
municipales, pues el comercio se había trasladado a la hacienda de Pedernales en detrimento del local. Señalaron que la geografía de la región obró en contra de los comerciantes de Turicato, ya que era difícil llegar al pueblo vecino. ${ }^{37}$ Insistieron en denunciar los insultos que el cura lanzaba contra los pocos vecinos que asistían a la misa dominical..$^{38} \mathrm{El}$ ejemplo ayuda a entender la participación de las autoridades locales en los asuntos eclesiásticos de los pueblos, pues de estar bien atendidos o no dependía que la vida cotidiana y económica no sufriera alteraciones en detrimento de los ingresos municipales y, sobre todo, del orden público.

\section{OCAMPO Y LA POLÉMICA DE LAS OBVENCIONES}

Al despuntar la segunda mitad del siglo XIX, el cobro de obvenciones y de los derechos parroquiales en el obispado de Michoacán continuó siendo un foco de discordia entre la feligresía y los párrocos y, por extensión, entre el poder civil y eclesiástico. Las disputas cotidianas que generaban los cobros tensaron el ambiente político, hasta convertirse en un problema de difícil solución para la mitra y gobierno estatal.

Melchor Ocampo, consciente de los problemas sociales que el cobro de las obvenciones generaba y tratando de encontrar una salida política, en su carácter de senador, envió el 8 de marzo de 1851 al congreso de Michoacán una representación para reformar el reglamento de aranceles parroquiales. Para el senador, la relación del gobierno de la república con la Iglesia tenía que modificarse conforme a los designios liberales para que la libertad de conciencia fuera respetada, así como el derecho del poder civil a intervenir en los asuntos religiosos. Apuntó que lo ideal sería mantener al clero a sueldo y realizar una amplia reforma en los manejos y administración de sus fondos, dejando sólo en cierta libertad la parte correspondiente a la manutención del culto y sostenimiento de los curas, pero sin descuidar que dichos ingresos fueran empleados para ese fin.

La reforma planteada por Ocampo proponía un cambio sustancial en la relación entre la Iglesia y el Estado, otorgando a este último el control de los recursos destinados al mantenimiento del culto. Sabedor de lo difícil que sería modificar esa relación política, se limitó a conminar a la Iglesia de Michoacán a frenar los abusos en el cobro de los derechos parroquiales y para ello insistió, como paso fundamental, en reformar el arancel vigente y responder así a la realidad social que vivían los habitantes. De no atender la mitra la reforma exigió que, en su defecto, vigilara que los párrocos cumplieran con lo estipulado en el

\footnotetext{
${ }^{36}$ Ibid.

37 Ibid.

38 Ibid.
} 
arancel, sobre todo en lo referente a las consideraciones especiales que tenían los pobres. ${ }^{39}$

Insistió en que el arancel colocó a la feligresía a expensas de los párrocos, quienes lo aplicaron de manera ventajosa, cobrando sin distingo los derechos más altos, apoyados en la igualdad jurídica liberal obligándolos a cubrir por igual las contribuciones, sin considerar las diferencias de ingresos, y los cambios poblacionales habidos en el obispado, que habían reducido sus gastos en comida y vestido. Aunque reconoció que el sustento de los curas se complicaba debido a la resistencia de los fieles a contribuir, pero insistió que las sumas recibidas por obvenciones estaban por encima de sus méritos y trabajos.

Tratando de conseguir la reforma del arancel que protegería a los pobres, sacó a colación algunos abusos que cometían los sacerdotes: que no adoctrinaban a la feligresía, que no asistían a los entierros de los pobres y exigían a los indígenas en una exhibición el pago de la velación y de arras en los casamientos. Señaló que el cobro acarreaba problemas a los pobres y lastimaba a la familia. Puso especial atención en los abusos a los peones de haciendas a quienes se cobraban por adelantado los derechos de inhumación.

La propuesta de Ocampo recibió una rápida respuesta del clero de Michoacán y despertó una encendida polémica protagonizada por el cura Agustín Ramón Dueñas y por Clemente de Jesús Munguía en un folleto, publicado el 29 de marzo de 1851, firmado bajo el seudónimo de Un Cura de Michoacán. Calificaron de heréticos los planteamientos por atacar los derechos de la Iglesia. Señalaron las razones político-eclesiásticas que evitaron que, durante más de un siglo, el arancel sufriera modificaciones: la guerra de Independencia y la prolongada sede vacante de la diócesis. Incluso apuntaron que el propio Gómez de Portugal en 1832, después de realizar una profunda revisión del arancel, no consideró necesario reformarlo. ${ }^{40}$

Redujeron a calumnia las acusaciones hacia el clero de no cumplir con sus obligaciones, sobre todo en la enseñanza de la doctrina. Insistieron en que el congreso de Michoacán era el menos indicado para reformar o fijar los derechos parroquiales, ya que correspondía hacerlo a la Iglesia.

En el transcurso de 1851, Ocampo contestó la impugnación del cura en tres respuestas, que publicó en los meses siguientes En ellas, rebatió los argumentos del eclesiástico insistiendo en la veracidad de sus señalamientos. En las dos primeras, reafirmó las acusaciones hacia los curas en la aplicación de cobros, al

\footnotetext{
${ }^{39}$ R. ARREOLA CORTÉS, Obras completas de Don. Melchor Ocampo. La polémica sobre las obvenciones parroquiales en Michoacán, Morelia, Comité Editorial del Estado de Michoacán, 1985, tomo II, p. 55. El análisis de la polémica de Ocampo y el Cura de Michoacán se apoya básicamente en esta fuente de época.

40 Ibidem.
} 
señalar que exigían a los indígenas el pago de las obvenciones asignadas a los españoles; asimismo, volvió a insistir sobre el particular y comentó que los derechos exigidos a los indígenas eran excesivos; y tenían variaciones en los curatos, lo que abría la puerta a la discrecionalidad. Apuntó que los párrocos percibían además de las obvenciones otros ingresos importantes, vía fundaciones piadosas, capellanías, cofradías, hermandades y diezmo, que las hacían excesivas. Atendió con especial interés aclarar la razón por la cual envió la reforma al congreso estatal: las obvenciones eran una contribución propiamente civil, que se recaudaba bajo una ley específica y sus ingresos tenían propósitos de utilidad pública, por tanto, no había razón alguna para que el congreso local no estudiara una reforma del arancel. ${ }^{41}$

En la tercera, denunció la forma coludida en que curas y dueños de haciendas exigían el pago adelantado a sus trabajadores. La práctica casi feudal, apuntó, favorecía al hacendado, quien endeudaba al trabajador logrando el control de la mano de obra. Éste, señaló, acudía a los préstamos para cubrir las necesidades de vestido y obvenciones de casamiento o muerte de familiares. Concluyó que el endeudamiento hacía que el peón perdiera el amor por el trabajo haciéndolo proclive a la embriaguez e intentara fugarse de las haciendas, pues las deudas truncaban su libertad.

La observación de Ocampo de que la Iglesia debía mantenerse de donaciones voluntarias causó extrañeza en el Cura, quien con ironía recordó que la institución eclesiástica conseguía de esa manera sus recursos. Ridiculizó la sugerencia de sujetar al clero a sueldo del poder civil, pues el gobierno estatal con esfuerzos pagaba a sus empleados. Pidió que comprobara su acusación de que los curas cobraban una tarifa más alta a los indígenas; incluso señaló que estos tenían la facultad de rebajar o perdonar los derechos. ${ }^{42}$

Negó que los sacerdotes faltaran a sus obligaciones pastorales de asistir a los entierros de pobres. Aclaró que si bien los pueblos indígenas recibieron en tiempos coloniales servicios gratuitos en los entierros fue porque se combatía la idolatría, pero ese beneficio lo perdieron cuando el liberalismo colocó a éstos en igualdad jurídica con el resto de ciudadanos. Cuestionó la idea de que el congreso local podía reformar el arancel de obvenciones, pues la constitución de Michoacán negaba todo derecho para modificar el arancel; asimismo, sacó a colación otro punto, quizá el más importante, que la falta de un arreglo con Roma en el ejercicio del Patronato, impedía a los estados modificar las rentas eclesiásticas.

La única posibilidad real surgiría de un acuerdo común entre las autoridades civil y eclesiástica, pero correspondería al Congreso General, y no al estatal,

${ }^{41}$ Ibidem.
${ }^{4}$ Ibidem. 
realizar la reforma al arancel vigente. De no acatar la advertencia, los diputados locales recibirían una sanción canónica; en suma, rechazó la injerencia del poder civil para reformar el arancel de obvenciones, pues correspondía a la Iglesia $\mathrm{y}$, en este caso al obispo, hacerlo de lo contrario usurparía la soberanía que por derecho divino tenía para promover una reforma de ese tipo. ${ }^{43}$

En marzo de 1851, Ocampo, con renovados bríos, defendió sus argumentos. Retomó un punto de la polémica que sacó a colación el Cura, que sólo los obispos podían reformar el arancel y que el poder civil sólo lo sancionaba. Cuestionó la soberanía de la Iglesia en materia de obvenciones al afirmar que el gobierno de la república heredó los derechos que tenía el rey de España para arreglar los cobros del arancel. Aclaró que siendo gobernador del estado en 1846, acudió a Gómez de Portugal a fin de llegar a un acuerdo para reformar el arancel de manera secreta. El objetivo principal del encuentro fue obtener información fidedigna del prelado respecto a las obvenciones, para plantear futuros cambios en la materia, pero no pretendió sujetarse a su autoridad.

La resistencia de la Iglesia de Michoacán en la polémica preocupó a Ocampo, ya que temía que la tranquilidad pública resultara afectada. El temor se transformó en amenaza cuando el vicario capitular y futuro obispo de la diócesis Clemente de Jesús Munguía, rechazó que el congreso ejecutara reformas al arancel, bajo el argumento de que la diócesis se encontraba en sede vacante. Frente al encono y consciente de que las obvenciones podrían deteriorar la relación de ambas instancias, decidió concluir la pugna con el Cura como una medida para evitar la confrontación que podría alcanzar visos de una guerra religiosa. El medio político local, que conoció en la prensa los objetivos que perseguía la reforma, recibió con agrado la decisión del senador. ${ }^{44}$

Meses después, en junio de 1852, Ocampo resultó electo gobernador de Michoacán, y a los pocos días la prensa local hizo pública una amenaza de muerte; sus detractores políticos se deslindaron y señalaron que éste tenía enemigos incluso entre los liberales, en donde pudo producirse..$^{45}$ La radicalización política obligó al gobernador a poner fin a la polémica de las obvenciones sin que su propuesta tuviera éxito. El congreso de Michoacán nada resolvió sobre el particular y heredó el problema a la siguiente legislatura, que entraría en funciones en 1852. Munguía, por su parte, después de sortear graves problemas por haberse negado a jurar las leyes civiles, se consagró obispo en 1852, y anunció que realizaría una revisión del arancel para estudiar una posible reforma. ${ }^{46}$ Pero

\footnotetext{
${ }^{43}$ Ibidem.

${ }^{44}$ R. ArReola Cortés, Ocampo, Morelia, Michoacán, Universidad Michoacana de San Nicolás de Hidalgo, 1992, p. 107.

45Ibid., pp. 166-170.

${ }^{46}$ Carta de Clemente de Jesús Munguía, obispo de Michoacán, a Melchor Ocampo a propósito de la revisión de los aranceles eclesiásticos, incluido el pago de las obvenciones parroquiales, fechada el
} 
todo quedó en buenas intenciones, pues el asunto no volvería a ser tocado hasta que la revolución liberal lo retomó como un elemento central de su programa político.

\section{LA LEY DE 11 DE ABRIL DE 1857}

Como advertimos al principio, el 11 de abril de 1857 el presidente Comonfort promulgó la ley sobre derechos y obvenciones parroquiales, que derogó los aranceles vigentes así como toda prestación de servicio personal y tasaciones en pueblos y haciendas. La ley otorgó la exención del pago a los pobres que no contaran con recursos para su subsistencia y facultó a la autoridad local calificar la pobreza de los fieles. Esto convirtió al poder civil en árbitro político. El cobro indebido o negar los sacramentos por falta de pago haría objeto a los curas de una multa que, de no cubrirse, ocasionaría su destierro.

El gobernador de Michoacán giró instrucciones para asegurarse del cabal cumplimiento de la disposición liberal, en especial en lo referente a la exención del pago a los pobres. La aplicación de la ley provocó un conflicto político entre curas y autoridades civiles que se agravó con las instrucciones que el obispo Clemente de Jesús Munguía dictó para contrarrestar la disposición. ${ }^{47}$

El peso de su aplicación recayó en las distintas autoridades locales que actuaron como intermediarios de la feligresía frente los curas que se resistieron a acatar la ley de 11 de abril de 1857, llevando la relación al límite de la convivencia. Los puntos de conflicto suscitados por la entrada en vigor de la ley en los pueblos los abordaremos a partir de los presentados en el valle de Maravatío, en las cercanías de Morelia, la sede episcopal.

El 7 de junio de 1857 el ayuntamiento de Indaparapeo denunció al subprefecto de Zinapécuaro, que el cura del lugar no otorgaba los beneficios que concedió la ley de obvenciones a los pobres, a pesar de haberse comprobado que los interesados cumplían los requisitos..$^{48}$ El subprefecto remitió el caso al pre-

9 de febrero de 1852, en AHCM, Diocesano/Gobierno/Correspondencia/Autoridades Civiles/18481852, exp. 199, caja 39, año 1852, 2 fs.

${ }^{47} \mathrm{Al}$ respecto véase Representación del obispo de Michoacán al Supremo Gobierno pidiendo la revocación de la Ley de 11 de abril de 1857 sobre derechos y obvenciones parroquiales y en caso de no ser derogada, protestando contra sus efectos, Coyoacán, 4 mayo 1857, y la Circular diocesana normando la conducta de los Señores curas, sacristanes mayores y vicarios de su diócesis con motivo de la Ley de 11 de abril de 1857 sobre derechos y obvenciones parroquiales, Coyoacán, 8 mayo 1857, Cfr. Clemente de Jesús Munguía, Defensa eclesiástica en el obispado de Michoacán desde fines de 1855 hasta principios de 1858, México, Imprenta de Vicente Segura, 1858, pp. 301-321 y 323-326, respectivamente.

${ }^{48}$ Carta del ayuntamiento del pueblo de Indaparapeo al prefecto del Departamento de Morelia a propósito de la conducta política observada por el párroco de dicho pueblo que se negó a acatar la ley

Hispania Sacra, LXIII

128, julio-diciembre 2011, 681-706, ISSN: 0018-215-X 
fecto de Morelia, ${ }^{49}$ quien a fin de solucionar el conflicto le ordenó trasladarse a dicho pueblo, pero sin resultados, pues el cura se mantuvo firme en su decisión y negaba exentar del pago de obvenciones en bautizos a indígenas pobres, aun presentando la certificación del ayuntamiento. ${ }^{50} \mathrm{El}$ cura argumentó que el poder civil no tenía injerencia alguna en los asuntos eclesiásticos, así que los indígenas tendrían que hacer el esfuerzo de pagar los derechos; ${ }^{51}$ frente a la negativa, el ayuntamiento exigió al gobierno estatal resolver el problema, pero el cura continuó negando las dispensas de pobreza a la feligresía. ${ }^{52}$

Con todo, el subprefecto logró un acuerdo con el eclesiástico para otorgar los beneficios de la ley, ${ }^{33}$ pero la tregua duró poco tiempo, ya que los indígenas exigieron su salida al haber incidido en la separación del vicario titular del curato, bachiller Ignacio Valdovinos, bajo falsos informes enviados a la mitra, así que exigieron al gobernador interceder en su favor para revocar la orden de la mitra. ${ }^{54}$

El cobro de obvenciones en los pueblos de la Prefectura de Morelia ocasionó reacciones violentas; por ejemplo, José María Salto, párroco de Ucareo, negó en un trámite matrimonial en Purinciacuaro, la exención del pago a un pobre de solemnidad. La actitud lo enemistó con el feligrés, quien lo amenazó de muerte de no acceder a la solicitud. El cura se mantuvo en su postura. ${ }^{55} \mathrm{El}$ subprefecto exigió a la Prefectura someter al párroco, pues la desobediencia a las leyes federales dañaba la imagen del gobierno civil ante la opinión pública. La radicalización política no tardaría en aparecer en las autoridades locales frente a la aparente complacencia de sus superiores, y decidieron tomar la iniciativa. ${ }^{56}$

de federal de obvenciones parroquiales, en Archivo Histórico Municipal de Morelia, Fondo Siglo XIX, (en adelante AHMM), caja 79, exp. 4-G, 1857, 9 fs.

${ }^{49} \mathrm{Ibid}$.

50 Informe del subprefecto del Partido de Zinapécuaro al prefecto del Departamento de Morelia relativos a los problemas con el cura del pueblo de Indaparapeo y la ley de obvenciones parroquiales fechado el 27 de agosto de 1857, en AHMM, Fondo Siglo XIX, caja 79, exp. 4-H, año 1857, 3 fs.

${ }^{51} \mathrm{Ibid}$.

${ }^{52} \mathrm{Ibid}$.

${ }^{53}$ Informe del presidente del Ayuntamiento de Indaparapeo al prefecto de Morelia a propósito de la conducta política del párroco de dicho pueblo observada en la aplicación de la ley de obvenciones parroquiales, fechada el 10 de octubre de 1857, en AHMM, Fondo Siglo XIX, caja 79, exp. 4-J, año 1857,6 fs.

${ }^{54}$ Solicitud de las comunidades indígenas de los pueblos de Indaparapeo y Pío al gobernador de Michoacán de la revocación de la orden de separación eclesiástica del bachiller Ignacio Valdovinos, del curato del pueblo de Indaparapeo, en AHMM, Fondo Siglo XIX, caja 79, exp. 4-J, año 1857, 7 fs.

55 Informe de Rafael Ruiz, subprefecto de Zinapécuaro, al prefecto de Morelia, denunciando la mala conducta política de José María Salto, párroco del pueblo de Ucareo, en la aplicación de la ley de obvenciones parroquiales, en AHMM, Fondo Siglo XIX, caja 79, exp. 11, año 1857, 4 fs.

${ }^{56} \mathrm{Ibid}$. 
El 26 de agosto de 1858, el ayuntamiento de Indaparapeo solicitó al gobierno estatal instrucciones para proceder contra los curas que se negaban a fijar en sus parroquias la ley de obvenciones. ${ }^{57}$ El 29 de septiembre de 1858, el gobierno estatal recordó que la ley era clara: frente a la resistencia podía perseguir de oficio, multar o incluso desterrar a los párrocos..$^{58}$ Un mes después el ayuntamiento de Acuitzio denunció al prefecto del Norte de Michoacán que, una vez que fijó la ley en la parroquia de Undameo, el cura Rafael Zamudio suspendió los bautizos, cerró la iglesia y abandonó el curato. La medida indignó a las autoridades que exigieron a la mitra resolver el problema enviando un sustituto. ${ }^{59}$ El ejemplo fue seguido por José María Saucedo, cura de Tarímbaro, quien se negó a secundar la ley, señalando que cerraría los templos como lo instruyó Munguía cuando las autoridades fijaran la ley de obvenciones. ${ }^{60}$

Hasta ahora hemos constatado la negativa de los curas a hacer efectiva la exención del pago de las obvenciones, establecida en la ley del 11 de abril de 1857 a los individuos de probada pobreza. El problema seguramente se extendió al resto de las regiones de la jurisdicción episcopal, pues la posición de curas y autoridades locales se mantuvo firme a los argumentos que ambas partes defendían.

Los pueblos de la ribera del lago de Pátzcuaro no fueron la excepción, pues una vez que entró en vigor la ley los conflictos no tardaron en aparecer. El 11 de septiembre de 1858, el subprefecto, Miguel Aguado, denunció el conflicto suscitado con el cura, quien se negó a fijar la ley de obvenciones por considerar que dañaba los derechos de la Iglesia. El párroco señaló que no sería cómplice del poder civil, porque de acceder contravendría las instrucciones dictadas por el obispo. ${ }^{61}$

Las formas tradicionales de pago como el pindecuario, fueron objeto de disputas con los curas en los pueblos indígenas de Michoacán, aún después de promulgada la ley de obvenciones. El 22 de noviembre de 1858, la feligresía indígena de Santa Fe de la Laguna denunció la amenaza del cura Pablo Ramírez

\footnotetext{
57 Consulta del presidente del ayuntamiento del pueblo de Indaparapeo, al Prefecto de Morelia de cómo proceder contra los párrocos que oponen resistencia a la fijación de la ley de obvenciones parroquiales, en AHMM, Fondo Siglo XIX, caja 81, exp. 4-G, año 1858, 4 fs.

${ }^{58}$ AHMM, Fondo Siglo XIX, caja 81, exp. 4-I, año 1858, 2 fs.

59 Solicitud del teniente de Santiago Úndameo al prefecto del Distrito Norte de Michoacán de que se expulse a Rafael Zamudio, párroco de dicho lugar por oponerse a la ley de obvenciones parroquiales, en AHMM, Fondo Siglo XIX, caja 81, exp. 7-I, año 1858, 5 fs.

${ }^{60}$ Respuesta de José María Saucedo, cura del pueblo de Tarímbaro a propósito de la fijación en los cuadrantes de su parroquia en de la ley de obvenciones parroquiales, en AHMM, Fondo Siglo XIX, caja 81, exp. 6-H, año 1858, 5 fs.

${ }^{61}$ Informe de Miguel Aguado, subprefecto de Pátzcuaro al prefecto del Departamento de Morelia, a propósito de la negativa del párroco de dicho lugar a colocar la ley de obvenciones parroquiales en los cuadrantes de su parroquia, en AHMM, Fondo Siglo XIX, caja 81, exp. 3-F, año 1858, 8 fs.
} 
de abandonar el pueblo si la feligresía no pagaba lo previsto en el pindecuario. El subprefecto, llamó a su oficina al sacerdote y lo conminó a permanecer en la parroquia; sin embargo, el cura mantuvo su amenaza en relación a la tasación, y señaló que obedecería las instrucciones dictadas por el obispo para bloquear la ley de obvenciones. Para evitar que los indígenas se quedaran sin párroco, el subprefecto de Quiroga ordenó el arraigo del cura mientras recibía instrucciones del gobierno estatal; pero la medida, sólo ocasionó que el sacerdote dejara vacante el curato como lo informaron los indígenas el 24 de noviembre de 1858.62

Debe señalarse que los sacerdotes no dudaron en utilizar el púlpito para defender los intereses de la Iglesia. El 1 de agosto de 1859, el subprefecto de Zacapu denunció al bachiller Pedro Hilario Sánchez Torrado por atacar al gobierno federal. Envió parte del sermón dominical que leyó a la feligresía, culpándolo de degradar la religión y empeñarse en corromper las costumbres y el tradicional respeto que la población tenía a la Iglesia. La intención del subprefecto fue alertar al gobernador Epitacio Huerta, para que exigiera a la mitra detener los ataques del cura, pues de lo contrario sería desterrado. ${ }^{63}$

Meses después, el 13 de octubre de 1859, la subprefectura de Zacapu registró otro incidente que involucró a un eclesiástico, recibió una queja contra el cura José María Hernández, en el pueblo indígena de Naranja, aledaño a su sede política. ${ }^{64} \mathrm{El}$ teniente de Justicia denunció que el párroco pretendía elevar cuatro veces el costo de los oficios religiosos en honor de Santa Rosa de Lima, que era de cinco pesos y dos reales. Exigió el pago semanal del pindecua rio, que consistía en porciones de carne de res y cerdo, gallinas y pañuelos elevando el costo, por tanto, los indígenas principales se vieron obligados a suspender la celebración. ${ }^{65}$ La resistencia a cubrir los derechos y obvenciones

\footnotetext{
62 Informe de Juan Arellano, subprefecto de Quiroga, al Prefecto de Morelia denunciando la conducta política de Pablo Ramírez, párroco del pueblo de Santa Fe de la Laguna a propósito de la aplicación de la ley de obvenciones, en AHMM, Fondo Siglo XIX, caja 81, exp. 2-K, año 1858, 6 fs.

${ }^{63}$ Frente al golpe de estado que desconoció la Constitución de 1857 conducido por Miguel Miramón en Tacubaya, el gobernador electo de Michoacán, Santos Degollado abandonó su cargo para trasladarse a la ciudad de México. El 5 de febrero de 1858 el congreso de Michoacán, declaró un estado de sitio en la entidad y nombró a Epitacio Huerta gobernador interino, con facultades omnímodas, pues además del ejecutivo, tendría el mando militar y judicial. Los apremios militares obligaron al gobernador a convertir al estado en un punto de avanzada liberal; lo fortaleció militarmente e hizo lo propio en los estados vecinos. Al respecto véase R. ARreola Cortés, Epitacio Huerta: soldado y estadista liberal, México, SEP, 1967, (Cuadernos de lectura popular, 80) y J. ROMERo Flores, Historia de la ciudad de Morelia, Morelia, Editorial Escuela de Artes, 1928.

${ }^{64}$ Carta del subprefecto del pueblo de Zacapu a la Secretaría de Gobierno de Michoacán denunciando la conducta pública del bachiller Pedro Hilario Sánchez Torrado, cura de dicho lugar contra el gobierno federal, en AHCM, Diocesano/Gobierno/Correspondencia/Autoridades Civiles/1857-1861, caja 41 , exp. 251, año 1859, 2 fs.

${ }^{65} \mathrm{Ibid}$.
} 
establecidos, además del pindecuario, molestó al cura Hernández, quien amenazó con no volver a celebrar en ese pueblo; por su parte, el subprefecto denunció al gobernador Huerta la maniobra del cura a fin de que el militar, exigiera a la mitra detener los abusos del sacerdote ${ }^{66}$ La presión hacia la mitra para detener al cura aumentaron. El eclesiástico abandonó el curato de Zacapu cuando la subprefectura fijó, a principios de 1859, la ley de obvenciones, dejando como interino al cura de Teremendo, con instrucciones de no administrar ningún sacramento si los interesados no cumplían con el arancel. ${ }^{67}$

\section{MuNGUía, CARTAS PASTORALES Y DEFENSA EN EL PÚLPITO}

El panorama descrito en las páginas anteriores tiene entre sus múltiples explicaciones, las directrices emanadas de la alta jerarquía eclesiástica por conducto del obispo Munguía. Para comprenderlas mejor, es conveniente regresar al momento en que fue promulgada la ley de obvenciones, ya que una vez que el obispo valoró los alcances de la ley de 11 de abril de 1857, trató de contrarrestar sus efectos dictando al clero instrucciones para hacerle frente. En principio, el 8 de mayo de 1857, desde Coyoacán, donde se encontraba por orden del gobierno, debido a su oposición a la ley de desamortización, estableció los puntos que el clero de su diócesis debía seguir respecto al cobro de obvenciones. Las instrucciones fueron acompañadas de un exhorto al gobierno a reconsiderar la entrada en vigor de la ley de obvenciones, por atentar contra los intereses de la Iglesia, razón por la cual Munguía insistió en su revocación y se opuso a fijarla en los cuadrantes de las parroquias. ${ }^{68}$

La solicitud de revocación del obispo buscaba evitar otro golpe a la Iglesia, como el de 1833 con la reforma del diezmo. Consciente de la gravedad, elaboró un reglamento que debía ajustar las acciones de los curas en el cobro de obvenciones. Como primer punto hizo hincapié en las prerrogativas que tenían los pobres de solemnidad que estaban exentos del pago de obvenciones en cualquier trámite de fábrica, sacristía o sacramento, pues de hacerlo, privarían a sus

\footnotetext{
${ }^{66}$ Informe del subprefecto de Zacapu a propósito de la mala conducta del cura José María Hernández en el pueblo de Naranja en el cobro de los derechos parroquiales fechado el 13 de octubre de 1859, en AHCM, Diocesano/Gobierno/Correspondencia/Autoridades Civiles/1857-1861, caja 41, exp. 255 , año 1859,6 fs.

${ }^{67}$ Informe del Subprefecto de Zacapu a Epitacio Huerta, comandante general de Michoacán, sobre la conducta de José María Hernández, párroco de dicho pueblo en la administración de los sacramentos. En AHCM, Diocesano/Gobierno/Correspondencia/Autoridades Civiles/1857-1861, caja 41, exp. 256, 3 fs.

68 Solicitud de revocación de Clemente de Jesús Munguía de la ley de 11 de abril de 1857 de obvenciones parroquiales fechada el 8 de mayo en la villa de Coyoacán, en AHCM, Diocesano/ Gobierno/ Correspondencia/Obispos/1855-1857, caja 76, exp. 420, año 1857, 3 fs.

Hispania Sacra, LXIII

128, julio-diciembre 2011, 681-706, ISSN: 0018-215-X
} 
familias del sustento diario. En caso de duda, dejó a criterio del cura probar la pobreza. Obviamente, descartó la pompa en los sacramentos. También recomendó al clero no promover demanda alguna por obvenciones frente a la autoridad civil. Recordó que en caso de agotarse la congrua, el cura tenía que dar aviso a la mitra para que el culto no sufriera interrupciones que alteraran la vida religiosa y pública de los pueblos. La observación del prelado beneficiaba a los pobres y no se contraponía a la ley de obvenciones sino, al contrario, la respaldaba. La discrecionalidad otorgada a los curas para determinar quién caía en la categoría de pobre de solemnidad abrió la puerta al conflicto. Éste fue el origen de las disputas de curas y autoridades locales y feligresía. ${ }^{69}$

El cabildo eclesiástico de Michoacán, por su parte, el 18 de septiembre de 1858 cerró filas con el obispo y culpó al gobierno estatal de los problemas que ocasionó la ley de obvenciones; sobre todo, de la persecución y destierro de los curas. El cabildo se deslindó de toda responsabilidad en los conflictos sociales generados por la ley, y consideró que ésta puso en peligro la tranquilidad pública y el culto católico, al truncar la administración de sacramentos y la predicación. Los capitulares fueron contundentes contra el gobierno civil michoacano al señalar que la diócesis no tenía ninguna responsabilidad, en la promulgación de la ley. Culpó al gobierno estatal, por no atender el escenario de encono político-social que la ley de obvenciones provocaría, advertido por Munguía, el 8 de mayo de 1857.70

Acusó al gobierno de alentar la confrontación y llevar a los pueblos al vacío, sin importarle la tranquilidad pública y el culto, pues las autoridades locales, excediendo sus facultades, invitaban a la feligresía por medios públicos a no cubrir las obvenciones, incluso las oblaciones voluntarias. Subrayó la persecución y el sarcasmo de las autoridades contra los curas en la ejecución de la ley, que transgredía los derechos de la Iglesia y exigió un castigo ejemplar para las autoridades. Por último, planteó la suspensión en común acuerdo con la mitra de la ley para evitar un deterioro mayor a la relación de ambas instancias de poder. La posibilidad de llegar a un acuerdo se diluyó una vez que el gobierno de Michoacán declaró vigentes los decretos emitidos el 6 y 13 de abril de 1858 que gravaban al 60 por millar los capitales eclesiásticos. El objetivo fue obtener recursos para hacer frente a los gastos de guerra, medida que alarmó a la mitra, pues parte de sus ingresos por réditos pasarían a los fondos estatales. Munguía solicitó al canónigo José Guadalupe Romero un dictamen para elaborar la defensa. ${ }^{71}$

69 Ibid.

${ }^{70}$ Representación del cabildo eclesiástico de Michoacán al gobernador de dicha entidad en protesta por la entrada en vigor de la ley de obvenciones parroquiales fechado en Morelia el 18 de septiembre de 1858 en AHCM, Diocesano/Gobierno/Correspondencia/Obispos/1855-1857, caja 76, exp. 434, año 1858,18 fs.

71 Ibid. 
El canónigo, apoyado en principios que provenían del derecho natural, subrayó el atropello a la Iglesia, pues la medida era anticonstitucional y sacrílega, al gravar los ingresos piadosos. Se opuso a facilitar cualquier ayuda económica al poder civil al no tener ninguna facultad para disponer de los recursos eclesiásticos. El canónigo apoyó el discurso que Munguía utilizó en la defensa de los intereses de la Iglesia, llegando a un acuerdo tácito respecto a la posición que debería asumir frente al gobierno estatal. Buscar en momentos de crisis la opinión del cabildo estrechó la relación del obispo con la corporación capitular, ya que trató de aprovechar la experiencia de los canónigos..$^{72}$

La carta pastoral y el reglamento de Munguía polarizaron el ambiente político desatando quejas en los curatos, llevando al conflicto al poder civil y eclesiástico.

El 26 de diciembre de 1858, Pedro Hilario Sánchez Torrado, cura de Zacapu, señaló el conflicto que desató la posición civil y eclesiástica frente a la ley de obvenciones. Denunció cómo el subprefecto del lugar suspendió la lectura de la pastoral y prohibió atacar al poder civil en sus sermones.

El mismo sacerdote volvió a señalar a la mitra, el 2 de enero de 1859, que la presión del subprefecto de Zacapu no disminuyó, pues cuidaba que no leyera la pastoral del obispo. Pese a ello admitió que la realizó en la misa dominical durante tres semanas consecutivas, pero que desistió, sabedor de las represalias públicas que frente a la feligresía imponían a los curas las autoridades locales que desafiaban su autoridad. ${ }^{73}$ El ejemplo constata cómo en los pueblos de Michoacán el ambiente político enrareció con la ley de obvenciones, provocando la confrontación de curas y autoridades, pues ambos bandos se empeñaron en llevar hasta sus últimas consecuencias las instrucciones de sus mandos superiores.

En ese escenario de conflictividad era de suponerse que los párrocos no se quedarían cruzados de brazos y denunciarían los atropellos. El 19 de mayo de 1857 en apoyo al obispo, el cura de Colotlán, Jalisco, del vecino obispado de Guadalajara, subrayó que la ley de obvenciones sólo provocó que el enfrentamiento creciera y se radicalizara. Señaló que el agravio mayor de los liberales consistía en que no respetaban los límites de ambas instancias de poder, pues la ley de obvenciones coartaba la libertad e independencia de la Iglesia. Ese proceder unilateral, insistió, imposibilitó llegar a un acuerdo que hubiese reducido las desavenencias; prerrogativas que la Iglesia siempre trataba de respetar. Para el cura, el problema de fondo radicaba en que la ley abrió la posibilidad a la fe-

\footnotetext{
72 Ibid.

73 Informe de Pedro Hilario Sánchez Torrado, cura del pueblo de Zacapu a la mitra de Michoacán sobre la presión política del subprefecto del lugar a propósito de la lectura la pastoral del obispo Munguía a propósito de la ley de obvenciones parroquiales fechado el 2 de enero de 1859, en AHCM, Diocesano/Gobierno/Sacerdotes/Informes/1850-1853, caja 446, exp. 283, año 1858, 18 fs.
} 
ligresía de evadir el pago de las obvenciones, pues no descartó que los ricos así lo hicieran, apoyados por las autoridades locales. La única posibilidad de evitar la evasión era que los curas contaran con un padrón actualizado de la feligresía para distinguir a los pobres de solemnidad. Advirtió que la ley partía de un gran error, al afirmar que todos los curas cometían irregularidades en el cobro de los derechos, premisa falsa, ya que en las filas del clero mexicano había sacerdotes respetables y comprometidos con su labor que no merecían ese trato, aunque no dejó de reconocer que un sector del clero abusaba de la feligresía. ${ }^{74}$

Comparó la ley de obvenciones con el proyecto de contribuciones directas, el cual criticó porque no consideraban el impacto social que causarían a las clases menos favorecidas, pues los comerciantes trasladarían al consumidor el impuesto elevando los precios de los productos. Situación que equiparó con las obvenciones, ya que los comerciantes intentarían burlar el pago de las obvenciones. Los pobres sostendrían el culto, aunque no descartó que incluso ellos trataran de sacar provecho del marco legal, apoyados por la autoridad civil. El cura alertó sobre la posible evasión de los derechos eclesiásticos que podría presentarse de no tener el párroco un control estricto sobre la población..$^{75}$

Las protestas de los párrocos contra la ley de obvenciones, como la del cura de Colotlán, no rindieron los frutos esperados, pues el gobierno federal no dio marcha atrás. En consecuencia, el medio rural de la diócesis de Michoacán continuaría siendo escenario de conflictos en los años siguientes.

\section{CONSIDERACIONES FINALES}

El panorama descrito a lo largo de las páginas del presente trabajo permitió advertir con claridad los conflictos sociales que la aplicación de la política liberal en el cobro de los derechos y obvenciones parroquiales, desencadenó en el obispado de Michoacán en distintos momentos políticos. Dada la importancia del problema, como pudo advertir el lector, rastreamos los antecedentes que ese añejo problema propició entre los curas y feligresía en los pueblos de la diócesis, con un tercer invitado: las autoridades locales. Ello hizo evidente, que el pago de la renta eclesiástica estuvo siempre en la mesa de discusión. Dicha orientación permitió dotar al problema de una dimensión histórica mayor, que

\footnotetext{
74 Protesta del párroco del pueblo de Colotlán, Jalisco, dirigida a las autoridades eclesiásticas de la mitra del obispado de Michoacán, a propósito de la ley de obvenciones parroquiales, fechada el 19 de mayo de 1857, en AHCM, Diocesano/Gobierno/Sacerdotes/Informes/1854-1862, caja 447, exp. 325 , año 1857,24 fs.

75 Ibid.
} 
ayudó a armar un escenario real para conocer el avance secular y los efectos de la disputa, pasando por las formas de cobro; el pindecuario y arancel, así como sus intentos de reforma propuestos por Ocampo. El conflicto final lo propició la revolución liberal, con la ley de obvenciones del 11 de abril de 1857.

El escenario parroquial fue la arena donde la política liberal libró la batalla a fin de minar la presencia que la Iglesia tenía en la vida pública de la feligresía en distintos ámbitos. El tema tuvo como fondo las quejas recurrentes de la feligresía y autoridades locales sobre los abusos que los curas cometían en el cobro de la renta eclesiástica, que tuvo visos de radicalización en la medida que el avance secular se consolidó. La ley de obvenciones trató de resolver ese añejo problema y hacer justicia a los pobres como parte de su política social. El peso de su aplicación recayó en las distintas autoridades locales que fungieron como intermediarios de la feligresía y los curas.

Munguía llevó al extremo la relación con el poder civil y colocó a los curas párrocos y feligresía en una difícil situación que se agravó con sus instrucciones para contrarrestar sus efectos. Su beligerancia producto del ímpetu personal y visión de las cosas, hizo patente su falta de habilidad política para dialogar con el poder civil a fin de evitar el enfrentamiento. ${ }^{76}$ El cabildo eclesiástico de Michoacán no tuvo otra opción que cerrar filas con el obispo y acusó al gobierno liberal de alentar la confrontación y llevar a los pueblos al vacío. Con todo, debe señalarse que en el conflicto de las obvenciones parroquiales más allá de las leyes gaditanas, el problema se acentuó por la ausencia en el arreglo del Patronato, cuya indefinición violentó la relación de las dos esferas de poder, que hizo evidente el camino de romanización que tomaría la Iglesia mexicana.

\footnotetext{
${ }^{76}$ Para ahondar más en las ideas del obispo Clemente de Jesús Munguía véase los siguientes trabajos: J. Bravo Ugarte, Munguía obispo y arzobispo de Michoacán, 1810-1868 su vida y su obra. Homenaje en el centenario de su muerte, México, Editorial Jus, 1967, M. MARTíneZ, Monseñor Munguía y sus escritos, obra completa, Morelia, Fimax Publicistas, 1991, M. Olimón Nolasco, El incipiente liberalismo de Estado en México, México, Editorial Porrúa, Comisión Nacional de Derechos Humanos, 2009, P. MijAngos y GonZÁlez, The Lawyer of the Church: Bishop Clemente de Jesús Munguía and the Ecclesiastical Response to the Liberal Revolution in Mexico (1810-1868), tesis doctoral inédita, The University of Texas at Austin, 2009, y del mismo autor «Las vías de lo legítimo»: derecho natural y estado católico en la obra de Clemente de Jesús Munguía, Cuadernos del Instituto Antonio de Lebrija, 9, 2006, pp. 151-221., y M. García Ugarte, Poder político y religioso. México siglo XIX, México, LXI Legislatura Cámara de Diputados, IIS-UNAM, IMDOSOC, Miguel Ángel Porrúa, 2010.
} 